\title{
Reciprocity Between Britain and the Union
}

We are pleased to be able to announce that negotiations have now been brought to a satisfactory conclusion. The following remarks form the gist of a letter dated 27th July, 1948, which has been received by our President from Miss Neilson, secretary of the C.S.P.

The Committee of the Chartered Society has noted that no provision apparently exists under the South African Medical, Dental and Pharmacy Act which would enable the South African Medical Council to enter into an agreement for reciprocal legislation with an auxiliary body such as the C.S.P. This naturally rendered it impossible for further steps to be taken with that body.

Despite this, however, Miss Neilson points out that her Committee fully approves of reciprocity being granted to members of the South African Society of Physiotherapists. Such members, whilst not being actually placed as members of the C.S.P. will be eligible for enrolment on a Supplementary List maintained by her Society.

At the present time, many Australian and New Zealand physiotherapists have taken advantage of this provision.

Enrolment on this List entitles Dominion physiotherapists to practise in hospitals in Britain at the full scale of salary recommended for members of the Chartered Society and it is hoped that when South African physiotherapists visit England they will first notify our General Secretary who will get into touch with Miss Neilson on their behalf.

In short, this means that, whilst the C.S.P. is unable, through circumstances out of their control, to grant reciprocity to physiotherapists who have trained in the Union and have subsequently registered with the South African Medical and Dental Council, they are perfectly willing to accord reciprocity to all physiotherapists who are members of the South African Society of Physiotherapists.

\section{Notes from the Branches}

\section{Cape Province:}

The Annual General meeting was held in July, and was fairly well attended. Members are, however, asked to attend general meetings, and those readers who have not attended for a long time, might take special note of this request. The prosperity of any society depends on the active support of all members, and if the Cape Branch is to take its share in the Society's affairs, a greater interest in its functioning will have to be displayed by those who do not attend meetings regularly.

The new committee was elected as follows: Chairman, Miss Sutherland; Vice-Chairman, Sister Hargreaves; Hon. Secretary, Mr. Schermbrucker; Hon. Treasurer, Miss Goldman; Committee member, Miss Watson; with Miss Kerr and Miss Lees as coopted members.

The meeting heard, with regret, that Miss P. Rice, Hon. Treasurer since $I 946$, is leaving Cape Town probably for Kenya. She has the good wishes of her colleagues for success in her future activities.

All new members are heartily welcomed. Their names will appear in the next issue.

\section{C.E.C. NOTES}

Miss M. Elmslie, Senior physiotherapist at Pretoria Hospital, who is in England at present. has been elected as official representative of the S.A.S.P. at the International Congress on Physiotherapy which is to be held in London on September 23rd-25th. She has also been appointed to act as liaison officer in England between the Appointments Secretary and prospective applicants for posts in South Africa.
Miss Susie Oosthuizen has been invited by the S.A. Association of Occupational Therapists to act on their Advisory Board for the ensuing year.

In the absence of Miss $M$. Catt, who is still in England, Mrs. J. M. Corder has kindly undertaken to act as alternate on the Auxiliaries Committee of the S.A. Medical Council. Accompanied by Miss C. $G$. Troughton, she attended a meeting of that committee on August 9th.

We welcome Miss Jean Blair back from her trip to England.

\section{CORRESPONDENCE.}

Sir,

Having experienced the diffidence of physiotherapists to put pen to paper and write articles for their journal, the idea has occurred to me that, while feeling doubtful about writing a lengthy paper for publication, many might give short accounts of specific treatments which they have tried, successfully, in the form of a letter to the Journal.

As an example, I give the essential points of my own methods of dealing with a stiff hand.

I employ faradism, as a routine, not only on account of its physiological effects but because of its profound psychological stimulus to the patients' active efforts. The patients see the current moving the fingers, their interest is stimulated, and their cooperation is the more readily obtained. Secondly, some torm of heat, either diathermy or infra-red radiation, follows. The hand becomes sufficiently supple for gentle, passive manipulations, and then, par excellence, active movements, occupational exercises and vigorous encouragement for the patients to perform these movements in the interval between treatments. It would be interesting to hear from other readers on this subject, surely one of the most arduous for the physiotherapist.

G. S. Schermbrucker, 